\title{
Feather Biodegradation For Feather Protein Lysate/ Feather Meal Mutual Formations: Optimization Using Crude YNDH Protease/Keratinase; Enzyme Partial Purification and Characterization
}

\section{Doaa Goda ( $\nabla$ doaa.rashid@yahoo.com )}

City of Scientific Research and Technological Applications

\section{Ahmad Bassiouny}

Alexandria University

Nihad Abdel Monem

Alexandria University

\section{Nadia Soliman}

City of Scientific Research and Technological Applications

\section{Yasser Abdel Fattah}

City of Scientific Research and Technological Applications

\section{Research Article}

Keywords: Purification, Characterization, thermo alkaline protease with keratinolytic activity, laceyella sacchari, feather lysate, feather meal

Posted Date: January 29th, 2021

DOl: https://doi.org/10.21203/rs.3.rs-138223/v1

License: (9) (i) This work is licensed under a Creative Commons Attribution 4.0 International License. Read Full License

Version of Record: A version of this preprint was published at Scientific Reports on July 15th, 2021. See the published version at https://doi.org/10.1038/s41598-021-93279-5. 


\section{Abstract}

Incubation parameters used for the production of a protein lysate from enzymatically degraded waste feather using crude keratinase produced by laceyella sacchari YNDH was optimized using RSM, amino acids quantification was estimated as well. The optimization resulted in total soluble protein $2089.5 \mu \mathrm{g} / \mathrm{ml}$. The optimal conditions were, time $20.2 \mathrm{~h}$, feather concentration $3 \mathrm{~g} \%$ and keratinase activity $24.5 \mathrm{U} / 100 \mathrm{ml}$ at pH, 10 ; and cultivation temperature $50^{\circ} \mathrm{C}$. The FPL was found enriched with essential and rare amino acids.

In parallel, this YNDH enzyme group had been partially purified and some characteristics of it were studied. Crude enzymes were first concentrated with Amicon Ultra 10k centrifugal filter, and then concentrated proteins were applied to "QFF" strong anion column chromatography. The partially purified enzyme has an estimated molecular masses ranged 6 to $10 \mathrm{kDa}$. The maximum enzyme activity was observed at $70^{\circ} \mathrm{C}$ and $\mathrm{pH} 10.4$ when measured by both casein and keratin azure as substrates. Interestingly, keratinolytic activity of this group was not affect by EDTA, PMSF and DTT. Generally the overall characters of this group protease/keratinase nearly the same when its activity was measured with both substrates suggesting that all these 3 protein bands working together as a group of keratinases.

\section{Introduction}

Keratin is predominantly found in tissues of reptiles, birds, amphibians, and mammals. He structural component of feathers, hair, nails, horns, hooves, bones, furs, claws, hides, bird beaks, skin, wool, scales, and bristle is made up of keratin

Although keratin processing is important for a wide range of applications, due to the large volumes of waste generated, efficient disposal of keratinous waste is of particular concern to the poultry and leather industries.

In the poultry industry, feathers are a significant by-product since they account for $5-7 \%$ of the The Chicken's body Weight and constituted of $91 \%$ of keratin protein, $8 \%$ water, and $1 \%$ of lipid ${ }^{1}$.Approximately several million tonnes of feathers are estimated to be created annually from the global poultry industry ${ }^{2}$.

Feathers have elevated keratin content, and consideration should be given to using this protein source. Conventional methods of degrading feathers such as alkali hydrolysis and steam pressure cooking not only destroy the amino acids but also require a huge amount of energy ${ }^{3,4}$. A cost-effective alternative way may be through biodegradation of the feathers from microorganisms using keratinase. Interestingly and recently, many potential applications have been linked to keratinase and related products ${ }^{5,6}$; such as feather meal production which apply as a supplement for feeding stuffs ${ }^{6,7}$.

The demand for industrial enzymes is estimated at USD 4.61 billion in 2016 and is expected to rise at a compound annual growth rate (CAGR) of 5.8 per cent between 2017 and 2022 and to cross USD 6.30 billion by $2022^{8}$. The unique characteristic that distinguishes keratinases from other pro-teases is the ability to bind to the complex and insoluble sub-strates (feathers, wool, silk, collagen, elastin, horns, stratum cor-neum, hair, azokeratin and nails) (8). Although the mechanism of enzyme adsorption is not yet well understood, it is known that the higher the adsorption capacity, the higher the degree of keratin hydrolysis ${ }^{9}$. In recent years, demands for 
keratinolytic proteases have increased in industrial applications such as feeding stuffs, fertilizers, detergents and textiles ${ }^{10}$.

The physical (e.g. steam pressure cooking) and chemical (e.g. alkaline hydrolysis) methods currently used for the conversion of feathers, in addition to being ecologically problematic and energy-intensive, are subject to loss of nutritionally essential amino acids ${ }^{11-13}$. Thus, feather biodegrdadation by microb /or enzyme using Keratinases formed by many microorganisms are considered to be an environmentally friendly approach to keratin waste recycling 6,7 .

\section{Materials And Methods}

\section{Enzyme production and préparation}

Protease/keratinase enzyme was produced in the optimized medium as reported previously by Goda ${ }^{36}$. After $48 \mathrm{~h}$ fermentation time; broth was collected in a beaker and kept at room temperature in static condition for $2 \mathrm{~h}$. Most of the bacterial cells were settled along with feather at the bottom of beaker, supernatant was decanted and then filtered through $0.2 \mu$ filters (MDI, India) using vacuum pump. This micro filtered supernatant was concentrated and used as crude enzyme, where it was using lyophilization technique, where the lyophilized enzyme was dissolved in glycine $\mathrm{NaOH}$ buffer $\mathrm{pH} 10$ and stored at $4^{\circ} \mathrm{C}$. Concentrated enzyme was used for feather degradation and feather meal production after required dilution.

\section{Lyophilization}

Lyophilization technique was carried out (lyophilizer; acculab, USA) to concentrate feather-lysate or enzyme in a powder form.

\section{Procurement of feather}

They procured chicken feather from the local market; were washed with detergent, and some washes with tap water accompanied by distilled water added detergent. Washed feather had been dried for $8 \mathrm{~h}$ at $50^{\circ} \mathrm{C}$ and used for subsequent experiments.

\section{Optimization process by Response surface methodology (Box-Behnken Design)}

Box-Behnken experimental design has been implemented in the present work to maximize the nutritional content mainly soluble protein of feather-lysate during the processing of the feather meal creation. Cleaned dried feathers were used as a biological substrate for tested YNDH protease/ keratinase crude enzyme, where the waste was processed in glycine $\mathrm{NaOH}$ buffer $\mathrm{pH} 10$ and incubated with enzyme at $50^{\circ} \mathrm{C}$.

The Response surface methodology was used to optimize the protein content of feather-lysate generated due to enzyme action. Two kinds of precipitates could be recognized, strong precipitate is rendered the feather meal after degradation of the waste-feather by enzyme, and the transparent supernatant constitutes the condensed soluble protein. An enhancement the protein concentration of lysate is considered the main aim of Box-Behnken Design (BBD) and reach to the end point of degradation (amino acids). Three variables (incubation time, 
substrate concentration and enzyme concentration were studied at three levels (high, medium and low) which were signified by $+1,0$ and -1 ; respectively, as shown in Table $1^{37}$.

The design matrix consisting of 14 trials shown in Table (1), was created to study the interaction between significant variables affecting feather degradation by the tested crude YNDH protease/keratinase enzyme; regarding soluble protein concentration as a response $(\mu \mathrm{g} / \mathrm{ml})$. Aliquots were collected at the stated time, centrifuged for $10 \mathrm{~min}$ at $10,000 \mathrm{rpm}$, and then the protein content of clear supernatant was measured at $750 \mathrm{~nm}$ $(\mu \mathrm{g} / \mathrm{ml})$ after subtracting from the blank which was taken at zero time. All cultures were conducted in triplicate, and the findings were used on average. This optimization method includes three key steps: conducting the statistically designed experiments, estimating the standardized mathematical model's coefficients and predicting the model's answer and testing its adequacy ${ }^{38}$.

\section{Enzymes activity}

Protease activity was carried out according to Anson ${ }^{39}$ using bovine casein as substrate and standard curve of tyrosine. While, keratinolytic activity was carried out according to the method of Suntornsuk $\mathbf{4 0}^{\mathrm{u}}$ using keratin azure as a substrate.

\section{Total protein estimation}

Lowery method was applied to estimate the total soluble protein concentration using standard curve of bovine serum albumin 41 .

\section{Amino acid analysis}

Amino acid contents of soluble protein lysate were determined using amino acid analyzer (chromatogaphy columns and consumables catalogue (SYKAM)

\section{Consolidation technique}

For usage of feather-lysate enriched with soluble protein as an animal supplement in adequate form, it was compressed into a dense solid using the Cold Pressing (CP) technique (Hydraulic Pressing Machine used for cold Pressing Consolidation). For cold pressing of protein lysate, a simple hydraulic press with $10 \mathrm{~mm}$ die is used, where protein lysate content in a powder form is put in a die, normally made of stainless steel, under a hydrostatic pressure of 5 tons (i.e. $0.6 \mathrm{GPa}$ ) and that pressure is sustained for $6 \mathrm{~min}$.

\section{Anion-exchange chromatography for protein purification}

The concentrated enzyme solution (10ml) was loaded into anion exchange ("QFF" strong column) coupled with a $20 \mathrm{mM}$ Tris base buffer $\mathrm{pH} 8.5$ using an automated ÄKTA Prime Plus method for the purification of proteases/keratinase. The column was washed off with 5 volumes of balancing buffer columns to remove the unbound proteins. The column-bound proteins were eluted with a linear gradient (0-100M) $\mathrm{NaCl}$ in $20 \mathrm{mM}$ Tris base buffer $\mathrm{pH} 8.5$ at a flow rate of $1 \mathrm{ml} / \mathrm{min}$ and fraction size of $5 \mathrm{ml}$. Fractions containing keratinolytic protease were pooled, desalinated and concentrated by the Amicon-10 ultrafiltration concentrator (20 kDa cut off membrane). 


\section{SDS-polyacrylamide gelelectrophoresis and zymography}

Sodium dodecyl sulfate polyacrylamide gel electrophoresis (SDS-PAGE) was used to test the protein purity and to detect the protein molecular mass as defined in ${ }^{42}$ at $12 \%, 15 \%$ and $17 \%$ polyacrylamide concentrations where a protein standard was used and running under the same conditions. After running, the gel was stained with Coommassie brilliant blue R-250 at $12 \%$ SDS and silver stain at 15 and $17 \%$ SDS ${ }^{43}$. Zymography is a simple and sensitive electrophoretic approach that can be used by Leber ${ }^{44}$ to image protein bands of protease with keratinolytic activity as transparent bands against the dark background, following a simple renaturation and staining procedure.

\section{Enzyme characterization}

The partially purified enzyme was characterized by studying the effects of temperature and $\mathrm{pH}$ on the activity and stability. Also, effects of some metal ions, surfactant, inhibitors and detergents were tested. The effect of substrate concentration (casein and keratin-azure) were also elucidated

\section{Effect of temperature and $\mathrm{pH}$}

To study the effect of temperature on the protease/keratinase enzyme activity; the reaction mixture was incubated at different temperatures ranging from 40 up to $90^{\circ} \mathrm{C}$ and 50 up to $90^{\circ} \mathrm{C}$ in $100 \mathrm{mM}$ glycine- $\mathrm{NaOH}$ buffer, $\mathrm{pH} 10$, using casein and keratinazure as substrate, respectively. The enzyme activity at different temperatures was determined and expressed in percentage relative to maximum value which constitutes $100 \%$. While, to study the effect of $\mathrm{pH}$ on activity the reaction mixture (enzyme - casein as substrate) was incubated at different $\mathrm{pH}$ values (7.6-11.6). The substrate was dissolved individually in $100 \mathrm{mM}$ of buffers: tris- $\mathrm{HCl}(\mathrm{pH} 7.6-$ 8.2), glycine- $\mathrm{NaOH}$ ( $\mathrm{pH}$ 9.6-10), $\mathrm{NaHCO}_{3}-\mathrm{NaOH}(\mathrm{pH} 10-10.8), \mathrm{Na}_{2} \mathrm{HPO}_{4}-\mathrm{NaOH}$ (pH 11.2-11.6). The enzyme activity at different $\mathrm{pH}$ values was determined and expressed in percentage as relative activity, where the reaction mixture was incubated at optimum temperature for $10 \mathrm{~min}$. When keratin-azure was used as substrate, it was dissolved individually in $100 \mathrm{mM}$ buffers: glycine- $\mathrm{NaOH}$ (pH 9.6-10), $\mathrm{NaHCO}_{3}-\mathrm{NaOH}(\mathrm{pH} 10-10.8)$. The enzyme activity at tested alkaline $\mathrm{pH}$ values was determined and expressed in percentage relative activity, where the reaction mixture was incubated at optimum temperature for $30 \mathrm{~min}$.

\section{Thermal and pH stability}

Thermal stability was assayed by incubating the studied partially purified enzyme at temperature ranging from $50-70^{\circ} \mathrm{C}$. The enzyme was pre-incubated at temperatures 50 and $55^{\circ} \mathrm{C}$, samples were withdrawn every hour along $24 \mathrm{~h}$, whereas at 60 to $75^{\circ} \mathrm{C}$; samples were withdrawn every $10 \mathrm{~min}$ up to $240 \mathrm{~min}$. The enzyme activity was measured after exposure to these conditions using casein and keratin azure as substrates and expressed in percent residual activity. To study the $\mathrm{pH}$ stability, the enzyme was pre-incubated for $1 \mathrm{~h}$ at room temperature at different pHs (9.6-10) \& (10-10.8) using glycine $\mathrm{NaOH}$ and, $\mathrm{NaHCO}_{3}-\mathrm{NaOH}$, respectively. Aliquots of the mixtures were taken each $10 \mathrm{~min}$ to measure the residual enzyme activity (\%) in reference to the control (untreated enzyme), where the optimum conditions of temperature and $\mathrm{pH}$ were applied in the reaction mixtures. $\mathrm{pH}$ stability was tested for all samples using casein and keratin azure as substrates.

Effect of some (metal ions), (surfactant, solvents), (activators, inhibitors) 
Effect of some metal ions on enzyme activity of partially purified enzyme was investigated using $\mathrm{CaCl} 2, \mathrm{MgSO}$, ZnSO4, $\mathrm{HgCl} 2$, CuSO4, $\mathrm{KCl}, \mathrm{MnCl} 2$, FeSO4, NiSO4, CoCl2, and FeSO4 at 1, 510,15 and $20 \mathrm{mM}$ final concentration. The enzyme was pre-incubated with the tested metal ion for $15 \mathrm{~min}$ at room temperature. Where, the effects of some surfactants as Triton X-100, Tween 20,40, 80 and SDS on enzyme activity were tested at $0.1,0.5,1$ and $2 \%$ final concentration and some of solvents such as ethanol, methanol and glycerol on protease activity was tested at 1 and $2 \%$ final concentration. Also, the influence of some inhibitors such as Phenyl Methyl Sulfonyl Fluoride (PMSF), Di-Thio-Theritol (DTT) and Ethylene Diamine Tetra Acetic acid (EDTA) on enzyme activity was investigated at 1,5 and $10 \mathrm{mM}$ final concentration. The enzyme was pre-incubated with each chemical (either solvents or inhibitors) for $15 \mathrm{~min}$ at room temperature; then the residual activity was determined as mentioned before using casein as substrate for all concentrations and the more promising conc. (final conc.) was tested using keratin-azure as substrate. The enzyme activity without any tested metal ion/or agent was taken as $100 \%$, each under optimum conditions of temperature and $\mathrm{pH}$.

\section{Effect of different substrate concentration (casein and keratin azure) on enzyme activity}

Kinetic constants $\left(\mathrm{V}_{\max }\right.$ and $\left.\mathrm{K}_{\mathrm{m}}\right)$ were determined using Lineweaver-Burk double reciprocal ( $1 / \mathrm{v}$ versus $\left.1 / \mathrm{S}\right)$ plot 45 ,by assaying fixed amount of tested enzyme with varying final concentrations of casein substrate (0.1$2 \%)$ prepared in $100 \mathrm{mM} \mathrm{NaHCo}-\mathrm{NaOH}$ buffer $\mathrm{pH}(10.4)$ incubated for $10 \mathrm{~min}$ at $70^{\circ} \mathrm{C}$. and for keratin azure as substrate by assaying fixed amount of tested enzyme with varying final concentrations of keratin-azure substrate $(1 \mathrm{mg}-10 \mathrm{mg})$ prepared in $100 \mathrm{mM} \mathrm{NaHCo3}-\mathrm{NaOH}$ buffer $\mathrm{pH}(10.4)$ incubated for $30 \mathrm{~min}$ at $70^{\circ} \mathrm{C}$.

\section{Results}

\section{Optimization the enzymatic degradation of waste feather for FPL production and feather meal formation using YNDH protease/keratinase crude enzyme.}

In order to achieve the optimum response area for maximizing the protein contents of enzymatically degraded feather in form of concentration $\left(\mu \mathrm{g} \mathrm{ml}^{-1}\right)$, the significant independent variables [X1; time (h), X2; feather concentration (g), X3; keratinase activity $(\mathrm{U} / \mathrm{ml})$ ] were further explored, each at three levels. Table 1 represents the design matrix of the variables in coded units with the experimental results of the protein lysate concentration. All cultures were conducted in triplicates and the observations averaged.

\section{Multiple regression analysis and ANOVA test}

The three variables with fourteen trails were analyzed using linear multiple regression analysis approach and the percentage confidence rates (percent) were determined. The p-value from the ANOVA analysis for each response was determined to analyze the relationship between the variables at $90 \%$ or higher confidence level and the analysis of variance using ANOVA test in Box-Behnken experiment was generated and summarized in Table 2 which gives $p=0.0235$. Since the $p$-value indicated in the ANOVA Table is less than 0.05 , it is concluded that there is a statistically significant relationship among the studied variables at $95 \%$ confidence level $(p=0.05)$. The value of the determination coefficient $R^{2}=0.953$ for protein contents (concentration) of enzymatic feather-lysate, being a measure of fit of the model, indicates that about $4.7 \%$ of the total variations are not explained by protein contents concentration. The adjusted R-squared statistic is 0.85 . Presenting experimental results in the form of surface plots (Fig. 1) show that higher levels of protein contents concentration were attained with the coded 
values 0.52 of time, 1 of substrate concentration and 0.457 of enzyme concentration. The optimum values of the three variables analyzed as obtained from the maximum polynomial model point were calculated using the JMP programme and found to be: time, $20.2 \mathrm{~h}$; substrate concentration, $3 \mathrm{~g} / 100 \mathrm{ml}$ and enzyme concentration, $24.57 \mathrm{U} / 100 \mathrm{ml}$ with prediction calculated protein contents concentration equal to $2159.85 \mu \mathrm{g} / \mathrm{ml}$. Bench scale experiments showed that $Y$ value of $2089.5 \mu^{-1} \mathrm{ml}^{-1}$ was obtained, this means the calculated model accuracy was $96.7 \%$. In this study a statistical technique, of Box-Behnken design was shown to be efficient and reliable in selecting the statistically significant factors and finding the optimal concentrations of those factors. Thefore, the following conditions are considered to be near the maximum, based on the results obtained from the BoxBehnken method: time 20.2h, substrate concentration, 3g\%; enzyme concentration, $24.57 \mathrm{U} \%$; $\mathrm{pH} 10$ and cultivation temperature $50^{\circ} \mathrm{C}$, the protein contents concentration measured was $2159.85 \mu \mathrm{g} / \mathrm{ml}$. Finally we can conclude that, protein contents of enzymatically degraded feather by effect of keratinase from Laceyella sacchari strain (YNDH) has been systematically improved during various experimental designs compared with basal medium.

\section{Amino acid analysis of feather meal}

In this experiment the feather lysate were analyzed for free amino acids released during feather degradation in both cell free supernatant after cultivation of laceyella sacchrii YNDH in optimized medium and feather hydrolysate produced due to enzymatic treatment as shown in Table 3 ( $A$ and B), respectively. 16 amino acids were detected in both experiments and quantified as shown in Table 3. Presence of essential amino acids like leucine and isoleucine indicates that feather treatment with the native isolate YNDH and YNDH crude keratinase enzyme provided feather lysate enriched with rare amino acids. The present study clearly shows that the degradation of the feather by YNDH keratinase provided by Laceyella sacchari is not only economical but also a viable method for the better use of the much disregarded feather wastes. Additionally we observed that the concentrations of all different types of amino acids produced through treatment of feather using keratinase developed by laceyella sacchari YNDH was significantly higher than that in feather hydrolysate produced by the native organism directly.

\section{Separation and collection of feather meal and protein lysate}

After optimization of enzymatic degradation of waste feather by YNDH protease/keratinase crude enzyme by Response surface methodology (Box-Behnken Design) the feather meal was settled down, centrifuged and dried at $50^{\circ} \mathrm{C}$, where, the supernatant containing protein lysate was lyophilized and consolidate the powder as shown as shown Figure 2.

\section{Protease / keratinase purification}

The cell free supernatant developed after cultivation was collected, added to Amicon Ultra centrifugal filter (cutoff of $10 \mathrm{kDa}$ ) to reduce the volume and remove protein impurities. This step is considered a partial purification step where it increased enzyme specific activity from $166.28 \mathrm{U} / \mathrm{mg}$ to $296.38 \mathrm{U} / \mathrm{mg}$ and purification fold by 1.78 as shown in (Table 4).

For ion exchange chromatography the working $\mathrm{pH}$ should be at least one higher than the $\mathrm{Pl}$ of the protein. At this $\mathrm{pH}$ value the protein will possess a net charge high enough to bind well to ion exchange resin. The concentrated and desalted cell free supernatant was subject to "QFF" strong anion column chromatography which was 
equilibrated with $20 \mathrm{mM}$ Tris- base buffer $\mathrm{pH}$ 8.5. The elution was performed with $1 \mathrm{M} \mathrm{NaCl}$ in the same buffer.

The elution profile (Figure 3 ) indicates that the protease with keratinolytic activity was detected in fractions 6-8. Upon using "QFF" strong anion column, enzyme was purified to 11.31 fold with specific activity and recovery of $1881.3 \mathrm{U} / \mathrm{mg}$ and $14.38 \%$, respectively (Table 4). The pooled fractions were loaded and run on 12,15 and $17 \%$ SDS-PAGE to detect the purity. Fig. 4 illustrates the pattern of protein profile before and after purification indicated by reduction in proteins bands to a 3 protein bands at molecular weight of (6 to 10) kDa (Fig. 4).

\section{Characterization of the partially purified protease/keratinase enzyme}

Certain characteristics of the partially purified enzyme under study were evaluated using casein and keratinazure substrates. Some parameters such as optimum temperature and $\mathrm{pH}$, thermal and $\mathrm{pH}$ stability, some enzyme inhibitors/ activators, surfactants, detergents, metal ions, and substrate concentration were investigated.

\section{Temperature and pH optimum}

The effect of temperature on the partially purified enzyme was studied by measuring the activity at different temperature values from 40 to $90^{\circ} \mathrm{C}$ with an interval of $5^{\circ} \mathrm{C}$ and 50 to $90^{\circ} \mathrm{C}$ with an interval of $10^{\circ} \mathrm{C}$ using casein and keratin-azure as substrate, respectively. The results presented in Figure $\mathbf{5}$ showed that the optimum temperature of the partially purified enzyme when measured as both protease and keratinase activity was $70^{\circ} \mathrm{C}$, so it can be classified as a thermo active protease with keratinolytic activity and the three isolated bands could be worked together as a group of keratinase.

While, the effect of $\mathrm{pH}$ on partially purified enzyme activity was investigated by determining of the enzyme activity, first as protease at $\mathrm{pH}$ values (7.6-11.6); and second as keratinse at pH values (9.6-10.8). The pH activity profile of the enzyme (protease/keratinase) indicates that it has a broad pH range with an optimum at pH 10.4 as shown in Fig. 6.

\section{Thermal and pH stability}

In the present experiment, The effect of temperature on the thermal stability of partially purified enzyme was studied by exposing it to a range of temperatures $\left(50-55^{\circ} \mathrm{C}\right)$ for $24 \mathrm{~h}$ and $\left(60,70\right.$ and $\left.75^{\circ} \mathrm{C}\right)$ for $4 \mathrm{~h}$ then the residual activity was calculated where $(100 \%)$ is considered the activity of enzyme kept at room temperature. The enzyme activity was measured as described before and expressed in percent residual activity using casein/keratin-azure substrates (Data not shown).

In summary, the results showed that the enzyme was highly activated $(238.46 \%$ as protease and $185.4 \%$ as keratinase) at temperature $50^{\circ} \mathrm{C}$, moreover it still steady at $55^{\circ} \mathrm{C}$ up to $24 \mathrm{~h}$. However, the enzyme possessed its stability until reached $90 \mathrm{~min}$ at $60^{\circ} \mathrm{C}$ however, it lost about half of its activity at temperature $70^{\circ} \mathrm{C}$ (the optimum $\mathrm{T}$ for enzyme activity) after $60 \mathrm{~min}$. Moreover it was less stable when exposed to higher temperatures $\left(75^{\circ} \mathrm{C}\right)$.

The pH stability of the partially purified enzyme was investigated as protease and keratinase by measuring the residual activities after incubating the enzyme at $\mathrm{pH}$ ranging from 9.6 to 10.8 at room temperature for $60 \mathrm{~min}$ with time interval of $10 \mathrm{~min}$ and using casein and keratin azure as substrates. The obtained results indicated that the enzyme was highly stable in all tested pHs (Data not shown). 


\section{Effect of some metal ions,detergent, surfactant, solvents, and activators/ inhibitors}

The effect of some metal ions on the partial purified protease enzyme activity was examined by measuring the residual activity in the presence of $(1 \mathrm{mM}, 5 \mathrm{mM}, 10 \mathrm{mM}, 15 \mathrm{mM}$ and $20 \mathrm{mM})$ of each metal ion. All metal ions at concentrations $(1,5$ and $10 \mathrm{mM})$ significantly activated protease activity while $\mathrm{Hg}^{+2}$ and $\mathrm{Cu}^{+2}$ inhibited the enzyme to $3.3 \%$ and $18.3 \%$, respectively when measured as protease. Moreover, the most significant metals activated the proteolytic activity are $\mathrm{Mg}^{+2}$ and $\mathrm{Fe}+2$ where, $\mathrm{Mg}^{+2}$ significantly increased protease activity to 274.477 and 232.11 at $15 \mathrm{mM}$ and $20 \mathrm{mM}$, respectively. While $\mathrm{Fe}^{+2}$ significantly activated protease activity to $411.11 \%$ and $1577 \%$, at $15 \mathrm{mM}$ and $20 \mathrm{mM}$, respectively as shown in Table 5 . The response of studied enzyme as keratinase was investigated towards the previously mentioned; metal ions; detergent, surfactant, solvents; activators/inhibitors, at the most significant concentration $(20 \mathrm{mM}, 2 \% \& 10 \mathrm{Mm})$, respectively. As shown in Table 6; keratinolytic activity of the enzyme significantly activated (410.1\% \&179.33\%) by, $\mathrm{Fe}^{+2}$ and $\mathrm{Mg}^{+2}$, respectively.

On the other hand, the enzyme activity was investigated as protease and keratinase activity in the presence of some surfactants, detergents and solvents. The results represented in Table 5 indicated that a slight increase in the activity of partially purified protease/keratiinase enzyme when treated with Tween-20 and Tween-80 at different concentrations, where Tween-40 highly activated the proteolytic activity and keratiolytic activities to $149.3 \%$ and $205.4 \%$, respectively. A sharp increase in proteolytic activity with $219.6 \%$ was resulted by incubating the enzyme with TritonX-100 at (1\%), but it did not show any effect on keratinolytic activity. However, sharp decrease in the proteolytic/keratinilytic activities was resulted by incubating the enzyme with SDS. Moreover, ethanol, methanol and glycerol had no effect on protease/keratinase enzyme activity while glycerol activated keratinase activity.

Also, the enzyme activity was investigated in the presence of some activators and inhibitors such as EDTA (inhibitor of metallo-type proteases), DTT (reducing agent) and PMSF (a serine protease inhibitor), the results represented in Table 5\& 6 showed that both EDTA and DTT caused a slight increase in activity of the partially purified protease/keratinase when measured by both casein and keratin azure. While, PMSF a serine protease inhibitor significantly increased enzyme activity as both protease and keratinase at concentration of $10 \mathrm{mM}$ to $120.13 \%$ and $176.07 \%$, respectively.

\section{Effect of substrate concentrations}

The kinetic parameters ( $\mathrm{Km}$ and $\mathrm{Vmax}$ ) of the extracellular YNDH protease/keratinase enzyme for hydrolysis of casein and keratin-azure at $70^{\circ} \mathrm{C}$ and $\mathrm{pH} 10.4$ were determined by double reciprocal Lineweaver-Burk plot. Hydrolysis efficiency represented by $\mathrm{Km}$ and $\mathrm{Vmax}$ for casein is shown in Fig. 7A and these are $7 \mathrm{mg} / \mathrm{ml}$ and $384.6 \mathrm{U} / \mathrm{mg}$, respectively. While, the hydrolysis efficiency represented by $\mathrm{Km}$ and $\mathrm{Vmax}$ for keratin azure is shown in Fig. 7B, these are $7.2 \mathrm{mg} / \mathrm{ml}$ and $103 \mathrm{U} / \mathrm{mg}$, respectively. The estimated $\mathrm{Km}$ value indicated the affinity of enzyme towards the substrate, while $V$ max is an indication of the catalytic activity of an enzyme which is usually desired to be as high as possible; the high $V$ max estimated indicates the high efficiency of tested enzyme towards the substrate.

\section{Discussion}


Keratinases are very interesting from a biotechnological point of view; especially those of microbial origin compared with plant or animal sources, especially because they possess almost all the features desired for biotechnological applications. Among these biocatalysts high alkaline proteases, which alone account for about $40 \%$ of global enzyme sales worldwide ${ }^{14}$, were especially suitable for industrial use. It is primarily because of their high stability and performance in tough conditions.

Feather is degraded to feather meal used as animal feed, organic fertilizers, feed supplements as it consists of > $90 \%$ protein and is rich in hydrophobic amino acids and major amino acids such as cystine, arginine, threonine $\mathbf{5}$, 15. Hydrothermal processes are the most common method for making feeder meal where the feather is cooked at high temperature at high pressure. However, hydrothermal treatment results in degradation of essential amino acids such as methionine, lysine, tyrosine and tryptophan. Also, it has poor digestibility and low nutritional benefits ${ }^{3,16}$. In this respect, the microbial degradation of feather into feather meal has become more significant and new microbes are being considered for the efficient degradation of feather, up to now no more than $10 \%$ of feather degradation is recorded in the presence of keratinases ${ }^{17}$. Interestingly, the studied keratinase of laceyella sacchari YNDH strain was observed to completely degrade the feather into feather meal and protein lysate, in order to achieve this particular process, the parameters that regulated the enzymatic degradation of the feather to protein lysate were studied in an experimental design by Box-Behnken. A further analysis of variables (time, feather conc, and enzyme conc) were performed at three leveles, each of -1.0 and +1 , to address the optimum response region of the protein concentration in the feather lysate directly via action by the crude protease with keratinolytic activity. The R value for protein concentration $(\mu \mathrm{g} / \mathrm{ml})$ was 0.97 in this experiment. This value refers to the high correlation of the experimental value to the predicted values. As the optimal conditions realized from the optimization experiment were verified experimentally and compared to the predicted optimum of the model. The estimated protein conc. was $2089.5 \mu \mathrm{g} / \mathrm{ml}$, where, the predicted value from the polynomial model was $2159.8 \mu \mathrm{g} / \mathrm{ml}$. This high degree of accuracy $(96.7 \%)$ is an evidence of the model validation under the following optimal conditions: time, $20.2 \mathrm{~h}$, feather conc., $3 \mathrm{~g} \%$ and keratinase activity $24.5 \mathrm{U} / 100 \mathrm{ml}$ at $\mathrm{pH}, 10$; and cultivation temperature $50^{\circ} \mathrm{C}$.

The current process of bioconversion of feathers into feather protein lysate and feather meal is an enzymatic process in which no additional redox reactions have been observed. The process is not only simple and timesaving, but also economically viable as it does not require any bioreactor for feather degradation. Thus, bulk feathers can be easily recycled into amino acid and feather meal using this predicted new found keratinase produced by laceyella sacchari strain YNDH within $20 \mathrm{~h}$.

Worldwide, commercial poultry processing generates more than a million tons of feathers per year ${ }^{18}$, which are currently converted to feather meal by steam pressure and chemical treatments, these methods therefore degrade amino acids and require significant energy input. Consequently, keratin can be transformed to usable biomass, protein concentrate or amino acids using keratinolytic microorganism-derived proteases ${ }^{7}$. The nutritional improvement of the meal and the use of microbial feather protein lysate in feed studies have shown that keratinase therapy may significantly increase the digestibility of amino acids in feather keratin 19,20 .

In the present study, analysis of the feather lysate resulted from effect of crude keratinolytic protease of laceyella sacchari YNDH showed presence of 16 different amino acids. The feather hydrolysate contained good amount of essential amino acids (phenylalanine, valine, leucine and isoleucine) and rare amino acids as serine

Page $10 / 28$ 
and proline, along with the other amino acids more importantly the sulphur containing amino acids like methionine, these findings are in agreement with ${ }^{21}$. They reported that the feather lysates developed by a thermotolerant Streptomyces graminofaciens contained 20 amino acids. Additionally in this study it was observed that the concentrations of all different types of amino acids in feather protein lysate (feather treated by enzyme) was significantly higher than that in feather hydrolysate produced by the native organism directly, these findings are in agreement with Tiwary ${ }^{4}$ who reported that during fermentation more than $0.5-2 \%$ w/v of feather can be used and also essential amino acids are utilized by micro-organism which decreases the nutritional value of feather meal.

For further understanding the applied YNDH enzyme which characterize by dual functions protease/keratina; purification and intensive biochemical characterization were followed. Through purification steps from crude extract to the final step of separation using anion exchange ("QFF" strong anion column); the purity have been gradually improved which revealed 3 distinctive bands with low molecular weights (<=10 kDa) indicating a partial purification. Generally, bacterial keratinases molecular weights are varied between bacterial species. But, the reported results in this study disagreement with others ${ }^{22,23}$; they observed keratinase with a relatively low molecular mass (18 kDa) in Streptomyces albidoflavus and the higher molecular weight was observed in Kocuria rosea (240 kDa), respectively, and agree with Lange ${ }^{24}$ which reported that a combination of endoprotease, exoproteases, and oligopeptidase is required to bring about keratin degradation. Hence, the result of this work may be showed a novel group of keratinases with very low molecular weight equal and/or below 10 $\mathrm{kDa}$.

The effect of temperature on the activity of the partial purified protease with keratinolytic activity showed that the isolated enzyme and/or isozymes was capable of hydrolyzing casein and keratin azure substrates at a wide range of temperature from $40^{\circ} \mathrm{C}$ to $75^{\circ} \mathrm{C}$, but maximal at $70^{\circ} \mathrm{C}$ by using both casein and keratin azure. Therefore, this protein(s) could be classified as a thermoactive protease/keratinase enzyme and the three isolated bands could be worked together as a group of keratinase. Similarly, Habbeche $\mathbf{2 5}$ have reported the optimum temperature of keratinase was $70^{\circ} \mathrm{C}$. While, $\mathrm{pH}$ activity profile of this enzyme indicates a broad $\mathrm{pH}$ range (7.611.6) of activity, with a maximum at pH 10.4 when used casein/keratin-azure substrate. In summary the optimum protease/keratinase activity was observed at $\mathrm{pH} 10.4$, but by increasing the $\mathrm{pH}$ beyond 10.4 a rapid decline in protease activity was noticed. These findings are in agreement with several earlier reports showing $\mathrm{pH}$ optima of alkaline protease being close to $10.0^{26-29}$. The thermal stability of the partial purified protease/keratinase showed that it was activated at $50^{\circ} \mathrm{C}$ for $24 \mathrm{~h}$. Also it's possessed its stability until reached $90 \mathrm{~min}$ at $60^{\circ} \mathrm{C}$. On the other hand the investigated enzyme was completely inactivated at $75^{\circ} \mathrm{C}$ after $20 \mathrm{~min}$. The increased proteolysis rate of proteases at elevated temperatures has been reported to be one of the factors responsible for rapid thermal inactivation of these enzymes. As described by ${ }^{30}$. This is in agreement with alkaline protease obtained from Bacillus sp. ${ }^{26,31}$, and from Streptomyces clavligerus ${ }^{32}$. Where, the enzyme was stable at $\mathrm{pH} 9.6$ to 10.8 after $1 \mathrm{~h}$ incubation at each tested $\mathrm{pH}$. The effect of different metal ions and chemical compounds on the activity of partially purified protease/keratinase enzyme indicate that the enzyme activity was completely inhibited by $1 \mathrm{mM} \mathrm{HgCl}_{2}$ and $\mathrm{CuSO}_{4}$, which are in agreement with Patel and Sana ${ }^{28,33}$. While, the non-ionic surfactant like Tween-20, Tween-40 Tween-80 and Triton-X-100 demonstrate slight enhancement of enzyme activity with increase of its concentration from $0.1 \%$ to $2 \%$ and $0.1 \%$ to $1 \%$, respectively which are in agreement with Joo and Sana ${ }^{31,33}$. They reported an enhancement in alkaline protease activity by Triton-X-100 
and Tween-80. Also, PMSF is known to sulphonate the essential serine residue in the active site of the protease, resulting in a total loss of enzyme activity ${ }^{34}$. Unlikely, it caused activation for studied partially purified protease/keratinase enzyme at $10 \mathrm{mM}$ concentration.

For the kinetic parameters $\left(K_{\mathrm{m}}\right.$ and $\left.V_{\mathrm{max}}\right)$ of the protease with keratinolytic activity from Laceyella sacchari YNDH, the present work showed that our group of keratinase enzymes have the same affinity toward keratin azure and casein because $K_{\mathrm{m}}$ for keratin azure was nearly equal that for casein. So that, we can concluded that our group of keratinase enzymes working together as protease with keratinolytic activity enzymes. Moreover the $\mathrm{K}_{m}$ is independent of enzyme concentration and it is a true characteristic of the enzyme under defined condition of temperature, $\mathrm{pH},{ }^{35}$. Higher $\mathrm{V}_{\text {max }}$ and lower $\mathrm{K}_{m}$ indicate the efficiency of protease with keratinolytic activity from laceyella sacchari YNDH. The present study is the first one reported the enzymatic degradation of waste feather for feather protein lysate production and feather meal formation using a new found crude protease/keratinase from a local isolate laceyella sacchariYNDH. In addition the characteristic features of the partially purified enzyme concerning unusual low molecular weight make it may be classify as a new or novel protein.

\section{Conclusion}

The extracellular protease with keratinolytic activity enzyme produced from Laceyella sacchari YNDH, was purified using FPLC to almost 11.31 purification fold with specific activity of $1881.3 \mathrm{U} / \mathrm{mg}$ protein. The molecular weight of the partially purified Laceyella sacchari YNDH group (three active bands) of protease with keratinolytic activity was found to be ranged below $10 \mathrm{KDa}$, using sodium dodecyl sulphate polyacrylamide gel electrophoresis technique, representing three subunits and this enzyme possess promising characteristics.

The present study showed that the isolation of a novel strain of laceyella sacchari for the production of protease with keratinolytic activity it may produce a novel group of keratinases which demonstrated, production of enzymatic feather-lysate enriched with amino acids was optimized using YNDH-keratinase enzyme. The application results indicating the great potential of produced enzymes in diverse biotechnological processes

\section{Declarations}

\section{Acknowledgements}

The authors are extremely grateful to the City for Scientific Research and Technological Applications, Alexandria, Egypt, for providing all facilities to complete this work.

\section{Author details}

1 Bioprocess Development Department, Genetic Engineering and Biotechnology Research Institute (GEBRI), City for Scientific Research and Technological Applications (SRTA-city), Alexandria, Egypt.

${ }^{2}$ Biochemistry Department, Faculty of science, Alexandria University, Alexandria, Egypt.

\section{Author contributions}


Doaa A. Goda performed the experimental part of the work and wrote the main manuscript text. Ahmed R. Bassiouny prepared figures of the work. Nihad M. Abdel Monem performed the analysis. Nadia A. Soliman revised the manuscript. Yasser R. Abdel Fattah interpreted the data, substantively revised the manuscript and suggested the main point of this work.

\section{Competing interests}

The authors declare no competing interests.

\section{Availability of data and materials}

All data produced during this study are included in this published article.

\section{References}

1. Akhter, M., Wal Marzan, L., Akter, Y., \& Shimizu, K. Microbial Bioremediation of Feather Waste for Keratinase Production: An Outstanding Solution for Leather Dehairing in Tanneries. Microbiology Insights. 13, (2020).

2. da Silva, R.R. Keratinases as an alternative method designed to solve keratin disposal on the environment: its relevance on agricultural and environmental chemistry. J. Agric. Food Chem. 66, 7219-7221(2018).

3. Papadopoulos, M.C., El Boushy, A.R., Roodbeen, A.E. \& Ketelaars, H. Effects of processing time and moisture content on amino acid composition and nitrogen characteristics of feather meal. Animal Feed Science and Technology, 14(3), 279-290(1986).

4. Tiwary, E., \&Gupta, R. Rapid conversion of chicken feather to feather meal using dimeric keratinase from Bacillus licheniformis ER-15. J Bioprocess Biotech. 2(4), Article no. 1000123 (2012).

5. Brandelli, A., Daroit, D.J. \& Riffel, A. Biochemical features of microbial keratinases and their production and applications. Applied microbiology and biotechnology. 85(6), 1735-1750 (2010).

6. Gupta, R. \& Ramnani, P. Microbial keratinases and their prospective applications: an overview. Applied Microbiology and Biotechnology. 70 (1), 21-33(2006).

7. Onifade, A.A., Al-Sane, N.A., Al-Musallam, A.A. \& Al-Zarban, S. A review: potentials for biotechnological applications of keratin-degrading microorganisms and their enzymes for nutritional improvement of feathers and other keratins as livestock feed resources. Bioresource technology. 66(1), 1-11(1998).

8. Matikeviciene, V., Masiliuniene, D. \& Grigiskis, S. Degradation of keratin containing wastes by bacteria with keratinolytic activity. In Proceedings of the 7th International Scientific and Practical Conference . 1, 284289(2009).

9. Vidmar, B., \&Vodovnik, M. Microbial keratinases: enzymes with promising biotechnological applications. Food Technology and Biotechnology. 56(3) 312-328 (2018).

10. Hassan, M.A., Haroun, B.M., Amara, A.A. \& Serour, E.A. Production and characterization of keratinolytic protease from new wool-degrading Bacillus species isolated from Egyptian ecosystem. BioMed research international. (2013).

11. Dalev, P., Ivanov, I. \& Liubomirova, A. Enzymic modification of feather keratin hydrolysates with lysine aimed at increasing the biological value. Journal of the Science of Food and Agriculture. 73(2), 242-244 (1997). 
12. Cai, C.G., Lou, B.G. \& Zheng, D. Keratinase production and keratin degradation by a mutant strain of Bacillus subtilis. Journal of Zhejiang University Science B. 9(1), 60-67(2008).

13. Matsui, T. et al. Sustainable and practical degradation of intact chicken feathers by cultivating a newly isolated thermophilic Meiothermus ruber H328. Applied microbiology and biotechnology. 82(5), 941950(2009) .

14. Kirk, O., Borchert, T.V. \& Fuglsang, C.C., Industrial enzyme applications. Current opinion in biotechnology. 13(4), 345-351 (2002).

15. Coward-Kelly, G., Agbogbo, F.K. \& Holtzapple, M.T. Lime treatment of keratinous materials for the generation of highly digestible animal feed: Animal hair. Bioresource technology. 97(11), 1344-1352 (2006).

16. Wang, X. \& Parsons, C.M., Effect of processing systems on protein quality of feather meals and hog hair meals. Poultry Science. 76(3), 491-496(1997).

17. Tiwary, E. \& Gupta, Medium optimization for a novel $58 \mathrm{kDa}$ dimeric keratinase from Bacillus licheniformis ER-15: Biochemical characterization and application in feather degradation and dehairing of hides.Bioresource technology. 101(15), 6103-6110(2010).

18. Schrooyen, P.M., Dijkstra, J., Oberthür, R.C., Bantjes, A. \& Feijen, J. Partially carboxymethylated feather keratins. 2. Thermal and mechanical properties of films. Journal of agricultural and food chemistry. 49(1), 221-230 (2001)..

19. Williams, C.M., Lee, C.G., Garlich, J.D. \& Shih, J.C. Evaluation of a bacterial feather fermentation product, feather-lysate, as a feed Poultry Science. 70(1), 85-94 (1991).

20. Odetallah, N.H., Wang, J.J., Garlich, J.D. \& Shih, J.C. Keratinase in starter diets improves growth of broiler chicks. Poultry Science. 82(4), 664-670(2003).

21. Ganesan, T. \& rajarajan, M.D. Feather degrading actinomycetes: a biotechnological approach to environmental clean-up. Department of Plant Sci Tagore Arts College, Puducherry, 605(008), (2011)

22. Bressollier, P., Letourneau, F., Urdaci, M. \& Verneuil, Purification and characterization of a keratinolytic serine proteinase from Streptomyces albidoflavus. Applied and Environmental Microbiology. 65(6), 2570-2576 (1999).

23. Bernal, C., Cairo, J. \& Coello, N. Purification and characterization of a novel exocellular keratinase from Kocuria Enzyme and microbial technology. 38(1-2), 49-54 (2006).

24. Lange, L., Huang, Y. \& Busk, P.K. Microbial decomposition of keratin in nature-a new hypothesis of industrial relevance. Applied microbiology and biotechnology. 100(5), 2083-2096(2016).

25. Habbeche, A. et al. Purification and biochemical characterization of a mdetergent-stable keratinase from a newly thermophilic actinomycete Actinomadura keratinilytica strain Cpt29 isolated from poultry Journal of bioscience and bioengineering. 117(4), 413-421 (2014).

26. Beg, Q.K. \& Gupta, R. Purification and characterization of an oxidation-stable, thiol-dependent serine alkaline protease from Bacillus Enzyme and Microbial Technology. 32(2), 294-304 (2003).

27. Genckal, H. \& Tari, C. Alkaline protease production from alkalophilic Bacillus sp. Isolated from natural habitats. Enzyme and Microbial Technology. 39(4),703-710 (2006).

28. Patel, R.K., Dodia, S., Joshi, R.H. \& Singh, S.P., Purification and characterization of alkaline protease from a newly isolated haloalkaliphilic Bacillus sp. Process Biochemistry. 41(9), 2002-2009(2006). 
29. Doddapaneni, K.K. et al. Purification and characterization of a solvent and detergent-stable novel protease from Bacillus Microbiological Research. 164(4), 383-390 (2009).

30. Ghorbel, B., Sellami-Kamoun, A. \& Nasri, M. Stability studies of protease from Bacillus cereus BG1. Enzyme and Microbial Technology.32 (5), 513-518 (2003).

31. Joo, H.S., Kumar, C.G., Park, G.C., Paik, S.R. \& Chang, S. Oxidant and SDS-stable alkaline protease from Bacillus clausii I-52: Production and some properties. Journal of applied microbiology. 95(2), 267-272 (2003).

32. Thumar, \& Singh, S.P. Two-step purification of a highly thermostable alkaline protease from salt-tolerant alkaliphilic Streptomyces clavuligerus strain Mit-1. Journal of Chromatography B. 854(1), 198-203(2007).

33. Sana, , Ghosh, D., Saha, M. \& Mukherjee, J. Purification and characterization of a salt, solvent, detergent and bleach tolerant protease from a new gamma-Proteobacterium isolated from the marine environment of the Sundarbans. Process Biochemistry. 41(1), pp.208 -215(2006).

34. Kumar, C.G. Purification and characterization of a thermostable alkaline protease from alkalophilic Bacillus Letters in Applied Microbiology. 34(1), 13-17(2002).

35. Negi, S. \& Banerjee, R. Characterization of amylase and protease produced by Aspergillus awamori in a single Food research international. 42(4), 443-448 (2009).

36. Goda, D. A., Bassiouny, A. R., Monem, N. M. A., Soliman, N. A., \& Abdel Fattah, Y. R. Effective multi-functional biotechnological applications of protease/keratinase enzyme produced by new Egyptian isolate (Laceyella sacchari YNDH). Journal of Genetic Engineering and Biotechnology. 18(1), 1-12 (2020).

37. Abdel-Fattah, Y.R. et al. Application of factorial experimental designs for optimization of cyclosporin A production by Tolypocladium inflatum in submerged Journal of microbiology and biotechnology, 17(12), 1930-19362007)).

38. Abdel-Fattah, Y.R., Soliman, N.A., Yousef, S.M. \& El-Helow, E.R. Application of experimental designs to optimize medium composition for production of thermostable lipase/esterase by Geobacillus thermodenitrificans Journal of Genetic Engineering and Biotechnology, 10 (2), 193-200 (2012).

39. Anson, M.L. The estimation of pepsin, trypsin, papain, and cathepsin with hemoglobin. The Journal of general physiology. 22(1), 79 (1938).

40. Suntornsuk, W. \& Suntornsuk, L. Feather degradation by Bacillus sp. FK 46 in submerged cultivation. Bioresource Technology . 86(3), 239-243(2003).

41. Lowry, O.H., Rosebrough, J., Farr, A.L. \& Randall, R.J. Protein Measurement with the Folin phenol reagent. J biol Chem. 193(1), 265-275(1951).

42. Laemmli, U.K. Cleavage of structural proteins during the assembly of the head of bacteriophage T4. Nature. 227, 680-685(1970).

43. Mortz, , Krogh, T.N., Vorum, H. \& Görg, A. Improved silver staining protocols for high sensitivity protein identification using matrix-assisted laser desorption/ionization-time of flight analysis. Proteomics. 1(11), 1359-1363(2001).

44. Leber, M. \&Balkwill, F.R. Zymography: a single-step staining method for quantitation of proteolytic activity on substrate gels. Analytical biochemistry. 249(1), 24-28(1997).

45. Lineweaver, H. \& Burk, D. The determination of enzyme dissociation constants. Journal of the American Chemical Society. 56(3), 658-666 (1934). 
Tables

Table 1. BBD for selected 3 variables with coded and real values, observed results for released protein concentration in enzymatically treated feather.

\begin{tabular}{|c|c|c|c|c|c|c|c|c|c|c|}
\hline \multirow[t]{3}{*}{ Trial } & \multirow{3}{*}{$\begin{array}{l}\text { X1 } \\
\text { Time } \\
\text { (h) }\end{array}$} & \multirow{3}{*}{$\begin{array}{l}\text { X2 } \\
\text { Feather } \\
\text { conc. } \\
(\mathrm{g} \%)\end{array}$} & X3 & \multirow[t]{3}{*}{$x 1 * x 2$} & \multirow[t]{3}{*}{$x 2 * \times 3$} & \multirow[t]{3}{*}{$x 1 * x 3$} & \multirow[t]{3}{*}{$\mathrm{X} 1 * \mathrm{X} 1$} & \multirow[t]{3}{*}{$x 2 * x 2$} & \multirow[t]{3}{*}{$x 3 * x 3$} & \multirow{3}{*}{$\begin{array}{l}\text { Soluble } \\
\text { protein } \\
\text { conc. in } \\
\mathrm{FPL} \\
(\mu \mathrm{g} / \mathrm{ml})\end{array}$} \\
\hline & & & Keratinase & & & & & & & \\
\hline & & & $(\mathrm{U})$ & & & & & & & \\
\hline 1 & $-1(7)$ & $-1(1)$ & $0(30)$ & 1 & 0 & 0 & 1 & 1 & 0 & 797.50 \\
\hline 2 & $1(21)$ & $-1(1)$ & $0(30)$ & -1 & 0 & 0 & 1 & 1 & 0 & 982.50 \\
\hline 3 & $-1(7)$ & 1(3) & $0(30)$ & -1 & 0 & 0 & 1 & 1 & 0 & 1114.17 \\
\hline 4 & $1(21)$ & 1(3) & $0(30)$ & 1 & 0 & 0 & 1 & 1 & 0 & 1737.5 \\
\hline 5 & $-1(7)$ & $0(2)$ & $-1(10)$ & 0 & 0 & 1 & 1 & 0 & 1 & 194.16 \\
\hline 6 & $1(21)$ & $0(2)$ & $-1(10)$ & 0 & 0 & -1 & 1 & 0 & 1 & 417.50 \\
\hline 7 & $-1(7)$ & $0(2)$ & $1(50)$ & 0 & 0 & -1 & 1 & 0 & 1 & 402.50 \\
\hline 8 & $1(21)$ & $0(2)$ & $1(50)$ & 0 & 0 & 1 & 1 & 0 & 1 & 1649.1 \\
\hline 9 & $0(14)$ & $-1(1)$ & $-1(10)$ & 0 & 1 & 0 & 0 & 1 & 1 & 665.83 \\
\hline 10 & $0(14)$ & 1(3) & $-1(10)$ & 0 & -1 & 0 & 0 & 1 & 1 & 1359.1 \\
\hline 11 & $0(14)$ & $-1(1)$ & $1(50)$ & 0 & -1 & 0 & 0 & 1 & 1 & 849.16 \\
\hline 12 & $0(14)$ & 1(3) & $1(50)$ & 0 & 1 & 0 & 0 & 1 & 1 & 1774.1 \\
\hline 13 & $0(14)$ & $0(2)$ & $0(30)$ & 0 & 0 & 0 & 0 & 0 & 0 & 1619.1 \\
\hline 14 & $0(14)$ & $0(2)$ & $0(30)$ & 0 & 0 & 0 & 0 & 0 & 0 & 1670.8 \\
\hline
\end{tabular}

Table 2. Statistical analysis of BBD showing coefficients values, $t, p$-values, confidence level $\%$ for each variable on protein content of enzymatically treated feather and ANOVA results of the experiment. 


\begin{tabular}{|c|c|c|c|c|c|}
\hline \multirow[t]{2}{*}{ Intercept } & Coefficients & Standard Error & $\mathrm{t}$ Stat & P-value & Confidence level (\%) \\
\hline & 1645 & 150.8 & 10.9 & 0.0004 & \\
\hline $\mathrm{X} 1$ & 284.7 & 75.40 & 3.77 & 0.0194 & 98.05 \\
\hline $\mathrm{X} 2$ & 336.2 & 75.40 & 4.459 & 0.0111 & 98.88 \\
\hline $\mathrm{X} 3$ & 254.7 & 75.40 & 3.378 & 0.0278 & 97.28 \\
\hline $\mathrm{X} 1 * \mathrm{X} 2$ & 109.5 & 106.6 & 1.027 & 0.362 & 63.77 \\
\hline$x 2 * x 3$ & 57.91 & 106.6 & 0.543 & 0.6159 & 38.40 \\
\hline$X 1 * X 3$ & 255.83 & 106.6 & 2.398 & 0.0744 & 92.55 \\
\hline$X 1 * X 1$ & -491.66 & 119.2 & -4.123 & 0.014 & 98.54 \\
\hline$x 2 * x 2$ & 4.583 & 119.2 & 0.0384 & 0.9711 & 2.882 \\
\hline \multirow[t]{3}{*}{$x 3 * x 3$} & -487.50 & 119.2 & -4.088 & 0.0149 & 98.50 \\
\hline & Degree of freedom & & Mean Square & F Ratio & p-value \\
\hline & $\mathrm{df}$ & Sum of Squares & MS & $\mathrm{F}$ & Significance F \\
\hline ANOVA & & SS & & & \\
\hline Regression & 9 & 3770892.116 & 418988 & 9.209921 & 0.023528 \\
\hline Residual & 4 & 181972.4612 & 45493.12 & & \\
\hline Total & 13 & 3952864.577 & & & \\
\hline
\end{tabular}

Table 3. Free amino acids and their concentrations in cell free supernatant after growing Laceyella sacchari YNDH strain in the optimized medium contains feather waste at $1 \%$ concn. (A); and after addition the crude keratinase to the waste- feather (B). 


\begin{tabular}{|lll|}
\hline $\begin{array}{l}\text { Amino acid concentration. } \\
(\mu \mathrm{g} / \mathrm{ml})\end{array}$ & Amino acid \\
\cline { 1 - 1 } & A & \\
\hline 587.76 & 56.852 & Aspartic acid \\
\hline 164.74 & UD & Threonine \\
\hline 145.32 & 32.58 & Serine \\
\hline 577.44 & 42.227 & Glutamic acid \\
\hline 887.76 & 3.067 & Proline \\
\hline 527.24 & 23.466 & Glycine \\
\hline 686.06 & 6.724 & Alanine \\
\hline 339.30 & 6.992 & Valine \\
\hline 40.860 & 1.458 & Methionine \\
\hline 199.00 & 3.124 & Isoleucine \\
\hline 441.52 & 49.999 & Leucine \\
\hline 348.90 & 7.555 & Tyrosine \\
\hline 749.90 & 18.866 & Phenylalanine \\
\hline 103.72 & 28.358 & Histidine \\
\hline 213.68 & 6.413 & Lysine \\
\hline 287.74 & 13.714 & Arginine \\
\hline
\end{tabular}

Table 4 .Purification scheme of protease/keratinase enzyme produced by laceyella sacchari (YNDH)

\begin{tabular}{|llllll|}
\hline Purification steps & $\begin{array}{l}\text { Total } \\
\text { activity }(\mathrm{U})\end{array}$ & $\begin{array}{l}\text { Total } \\
\text { protein } \\
(\mathbf{m g})\end{array}$ & $\begin{array}{l}\text { Specific activity } \\
(\mathrm{U} / \mathrm{mg})\end{array}$ & $\begin{array}{l}\text { Purification } \\
\text { (fold) }\end{array}$ & $\begin{array}{l}\text { Yield } \\
\text { (\%) }\end{array}$ \\
\hline Crude (cell-free supernatant) & 39364 & 236.8 & 166.28 & 1 & 100 \\
\hline $\begin{array}{l}\text { Concentrated crude (using } \\
\text { Amicon Ultra 10K) }\end{array}$ & 16953 & 57.2 & 296.38 & 1.78 & 43.06 \\
\hline $\begin{array}{l}\text { Anion exchange using "QFF" } \\
\text { strong anion column }\end{array}$ & 5661 & 3.09 & 1881.3 & 6.34 & 14.38 \\
\hline
\end{tabular}

Table 5.Effect of different metal ions, detergents, surfactants, activators/ inhibitors on the activity of partially purified enzyme using casein substrate and measured as protease. 


\section{Residual activity of protease (\%)}

Tested Different metal ions at conc.

\begin{tabular}{|c|c|c|c|c|c|}
\hline & \multicolumn{5}{|l|}{ Mean \pm SD } \\
\hline & $1 \mathrm{mM}$ & $5 \mathrm{mM}$ & $10 \mathrm{mM}$ & $15 \mathrm{mM}$ & $20 \mathrm{mM}$ \\
\hline $\mathrm{Cu}^{+2}$ & $3.32 \pm 0.5$ & $4.66 \pm 3$ & $2.76 \pm 1.1$ & $2.33 \pm 0.57$ & $3 \pm 0.27$ \\
\hline $\mathrm{Co}^{+2}$ & $235.2 \pm 6.3$ & 378.61 & $171.3 \pm 2.9$ & $151.5 \pm 1.1$ & $3.2 \pm 0.01$ \\
\hline $\mathrm{Ca}^{+}$ & $145.4 \pm 3$ & 323.79 & $165.1 \pm 6$ & $136.0 \pm 0.9$ & $228.4 \pm 2.5$ \\
\hline $\mathrm{Hg}^{+2}$ & $18.37 \pm 1.7$ & 59.93 & $16.000 \pm 1.4$ & $2 \pm 0.15$ & $2.7 \pm 0.57$ \\
\hline$M g+2$ & $155.1 \pm 0.99$ & 281.3 & $289.1 \pm 3.9$ & $274.4 \pm 2$ & $232.1 \pm 1.7$ \\
\hline $\mathrm{Mn}^{+2}$ & $157.8 \pm 3.8$ & 278.6 & $98.44 \pm 2.1$ & $119.5 \pm 2.3$ & $1.2 \pm 0.2$ \\
\hline $\mathrm{Fe}^{+2}$ & $225.0 \pm 1.34$ & 195.7 & $208.6 \pm 1.6$ & $411.1 \pm 1.6$ & $1577 \pm 4.3$ \\
\hline $\mathrm{Ni}^{+2}$ & $174.6 \pm 4$ & 260.2 & $140.8 \pm 1.8$ & $134.2 \pm 2.1$ & $319.2 \pm 0.05$ \\
\hline $\mathrm{Zn}^{+2}$ & $244.5 \pm 2.2$ & 321.3 & $92.66 \pm 0.7$ & $62.61 \pm 1.9$ & $0.9 \pm 0.07$ \\
\hline Control & $100 \pm 0.0$ & $100 \pm 0.0$ & $100 \pm 0.0$ & $100 \pm 0.0$ & $100 \pm 0.0$ \\
\hline
\end{tabular}

\begin{tabular}{|lllll|}
\hline \multicolumn{5}{|c|}{ Detergents, surfactants and solvents at conc. } \\
& Mean \pm SD & & \\
\cline { 2 - 5 } & $0.1 \%$ & $0.5 \%$ & $1 \%$ & $2 \%$ \\
\hline Tween-20 & $114.6 \pm 3$ & $96.8 \pm 1.8$ & $127.6 \pm 1.5$ & $122.3 \pm 1.1$ \\
\hline Tween-40 & $113.1 \pm 2.7$ & $177 \pm 3.2$ & $164.7 \pm 1.52$ & $149.3 \pm 2$ \\
\hline Tween-80 & $96.2 \pm 3.2$ & $105 \pm 0.9$ & $122.8 \pm 1.51$ & $134.6 \pm 1.4$ \\
\hline SDS & $94.5 \pm 0$ & $21.3 \pm 1.3$ & $35.93 \pm 1$ & $0.7 \pm 1.1$ \\
\hline Methanol & $3.1 \pm 1$ & $7 \pm 2$ & $95.5 \pm 0.94$ & $100.8 \pm 2.5$ \\
\hline Ethanol & $7 \pm 2$ & $5.2 \pm 2.7$ & $125.2 \pm 0.51$ & $100.9 \pm 1.6$ \\
\hline Glycerol & $4 \pm 1$ & $6.6 \pm 2.5$ & $103.4 \pm 1.5$ & $104.2 \pm 2.1$ \\
\hline Triton-X100 & $92.2 \pm 1$ & $195 \pm 1.1$ & $219.6 \pm 1.6$ & $4 \pm 0$ \\
\hline Control & $100 \pm 0.0$ & $100 \pm 0.0$ & $100 \pm 0.0$ & $100 \pm 0.0$ \\
\hline & Activators/ inhibitors at conc. & \\
\hline & Mean \pm SD & & & \\
\hline
\end{tabular}




\begin{tabular}{|llll|} 
& $1 \mathrm{mM}$ & $5 \mathrm{mM}$ & $10 \mathrm{mM}$ \\
\hline EDTA & $94 \pm 5.5$ & $92.3 \pm 1$ & $93.5 \pm 0.7$ \\
\hline DTT & $102 \pm 2.4$ & $103 \pm 2$ & $100 \pm 1.3$ \\
\hline PMSF & $90.7 \pm 2.1$ & $112.9 \pm 2$ & $120.13 \pm 0$ \\
\hline Control & $100 \pm 0.0$ & $100 \pm 0.0$ & $100 \pm 0.0$ \\
\hline
\end{tabular}

Table 6.Effect of the most promising conc. of (metal ions, detergents, surfactants, activators and inhibitors) on the activity of partially purified enzyme using keratin-azure substrate and measured as keratinase. 


\begin{tabular}{|c|c|}
\hline \multicolumn{2}{|c|}{ Residual activity of keratinase (\%) } \\
\hline \multirow[t]{2}{*}{ Metals } & Metal ions at conc. $(20 \mathrm{mM})$ \\
\hline & Mean \pm SD \\
\hline $\mathrm{Cu}^{+2}$ & $3.2 \pm 2.96$ \\
\hline $\mathrm{Co}^{+2}$ & $1.33 \pm 2.3$ \\
\hline $\mathrm{Ca}^{+}$ & $164.33 \pm 4.5$ \\
\hline $\mathrm{Hg}^{+2}$ & $4.66 \pm 5.6$ \\
\hline$M g+2$ & $179.33 \pm 5.1$ \\
\hline $\mathrm{Mn}^{+2}$ & $3.66 \pm 2$ \\
\hline $\mathrm{Fe}^{+2}$ & $410.1 \pm 4.5$ \\
\hline $\mathrm{Ni}^{+2}$ & $120.3 \pm 3.6$ \\
\hline $\mathrm{Zn}^{+2}$ & $9 \pm 4$ \\
\hline \multirow[t]{3}{*}{ Control } & $100.0 \pm 0$ \\
\hline & Detergents; surfactants and solvents at conc. ( $2 \%)$ \\
\hline & Mean \pm SD \\
\hline Tween-20 & $161.20 \pm 0.23$ \\
\hline Tween-40 & $205.4 \pm 3.14$ \\
\hline Tween-80 & $165.75 \pm 2.4$ \\
\hline SDS & $62.45 \pm 3$ \\
\hline Methanol & $92.0 \pm 2$ \\
\hline Ethanol & $71.7 \pm 2$ \\
\hline Glycerol & $136.4 \pm 3$ \\
\hline Triton-X100 & $85 \pm 2$ \\
\hline \multirow[t]{3}{*}{ Control } & $100 \pm 0.0$ \\
\hline & Activators/ inhibitors at conc.(10mM) \\
\hline & Mean \pm SD \\
\hline EDTA & $114.8 \pm 3$ \\
\hline DTT & $124.7 \pm 1.5$ \\
\hline
\end{tabular}




\section{Figures}

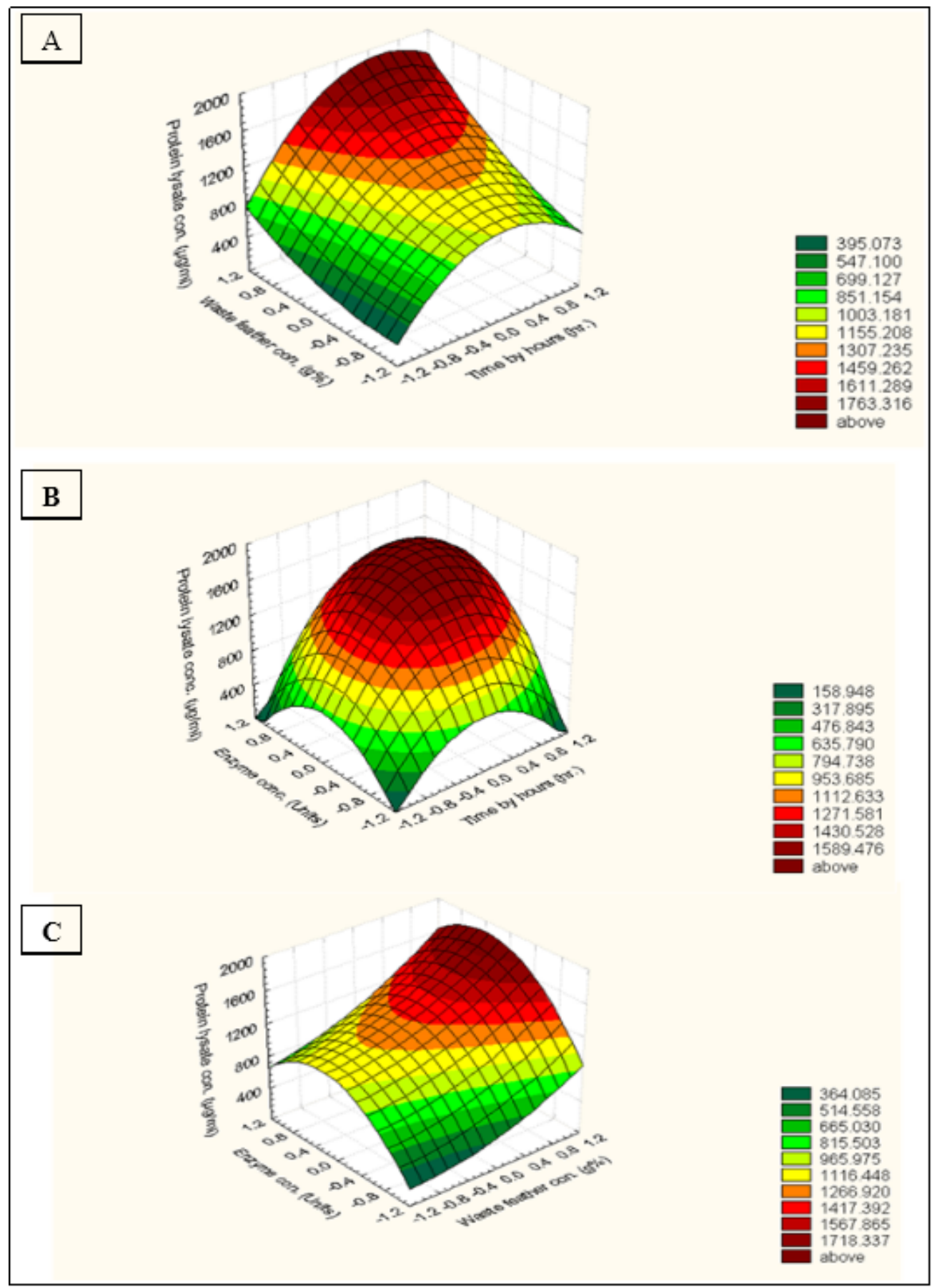

Figure 1

Three dimensional surface plots showing the relationships between the tested signifcant variables and protein concentration $(\mu \mathrm{g} / \mathrm{ml})$ in FPL production also the optimal levels of the three factors as obtained from the maximum of the polynomial model. The three figures indicate (A) the interaction between feather waste and 
time, (B) the interaction between enzyme conc. and time and (C) the interaction between enzyme conc. and feather waste.
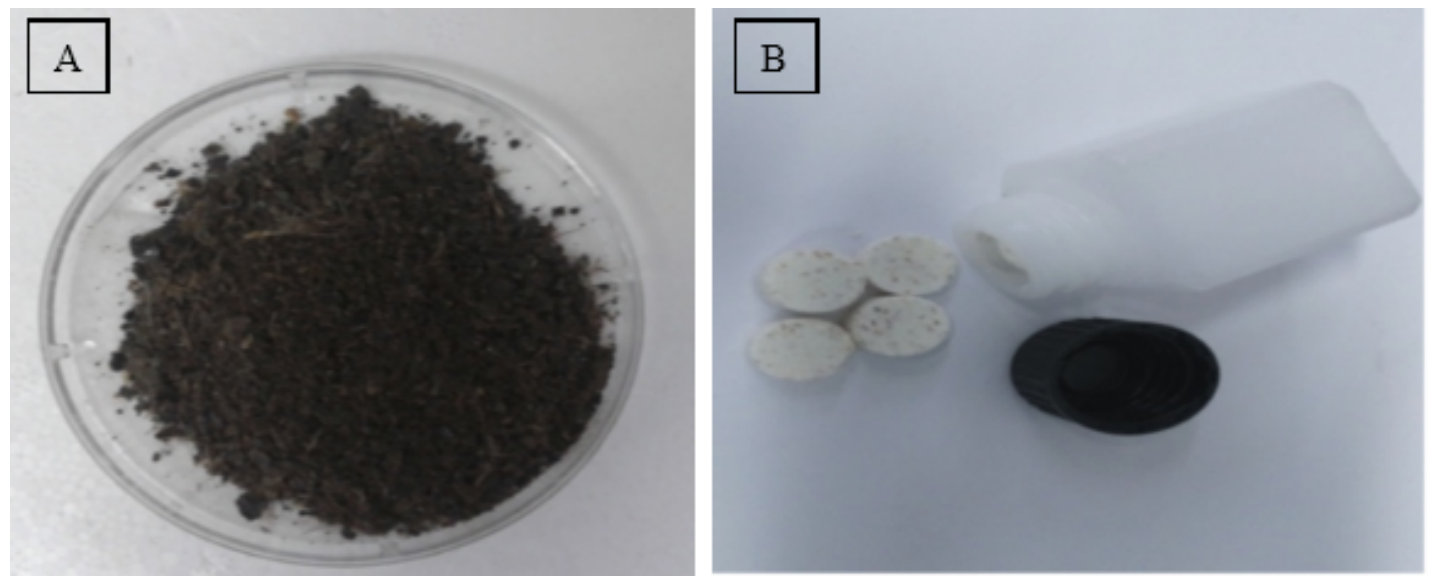

\section{Figure 2}

Final product from (A) Feather meal and (B) feather protein lysate (FPL) consolidate. 


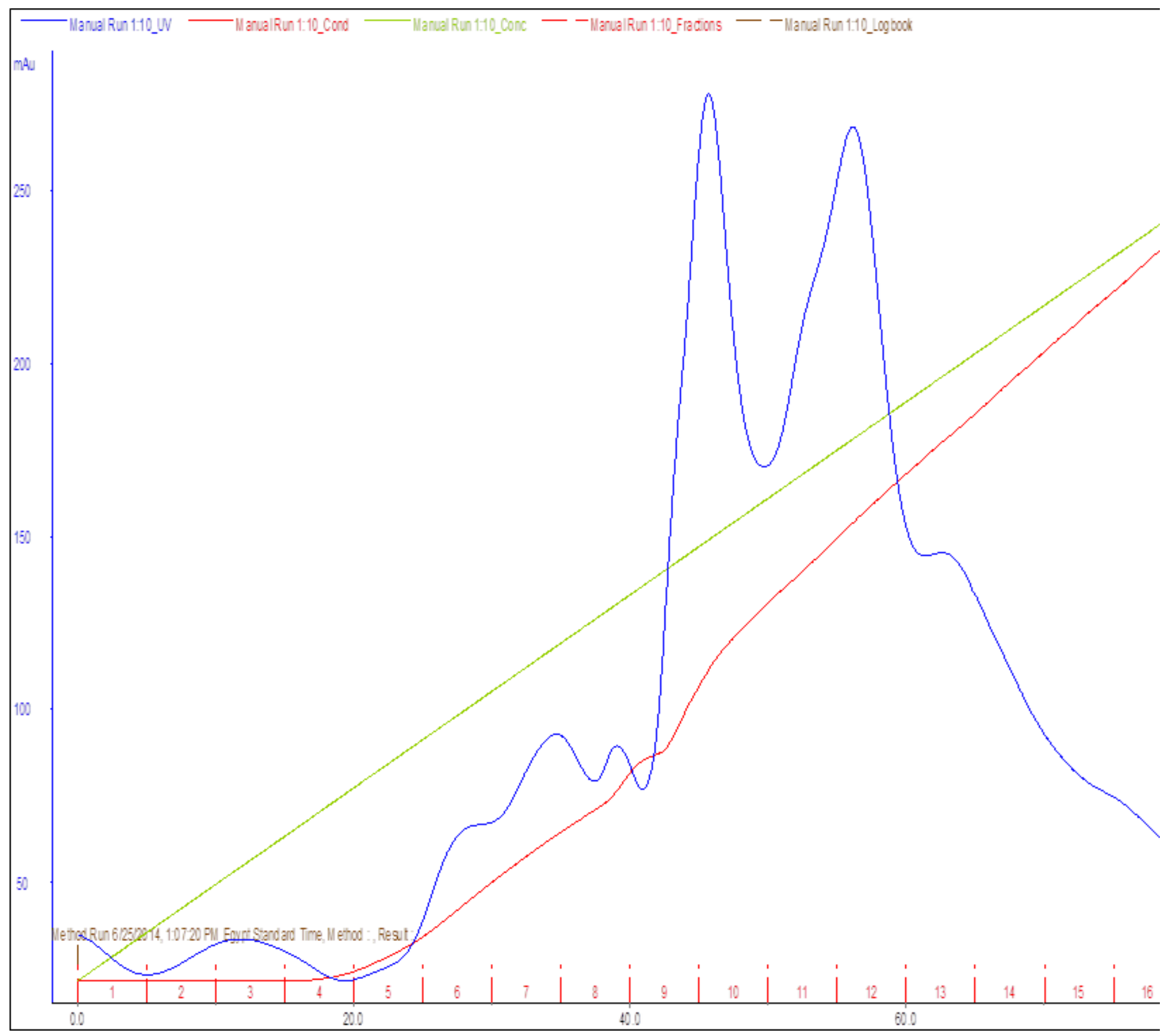

Figure 3

Elution profile of protease/keratinase enzyme after loading on"QFF" strong anion exchange column. 


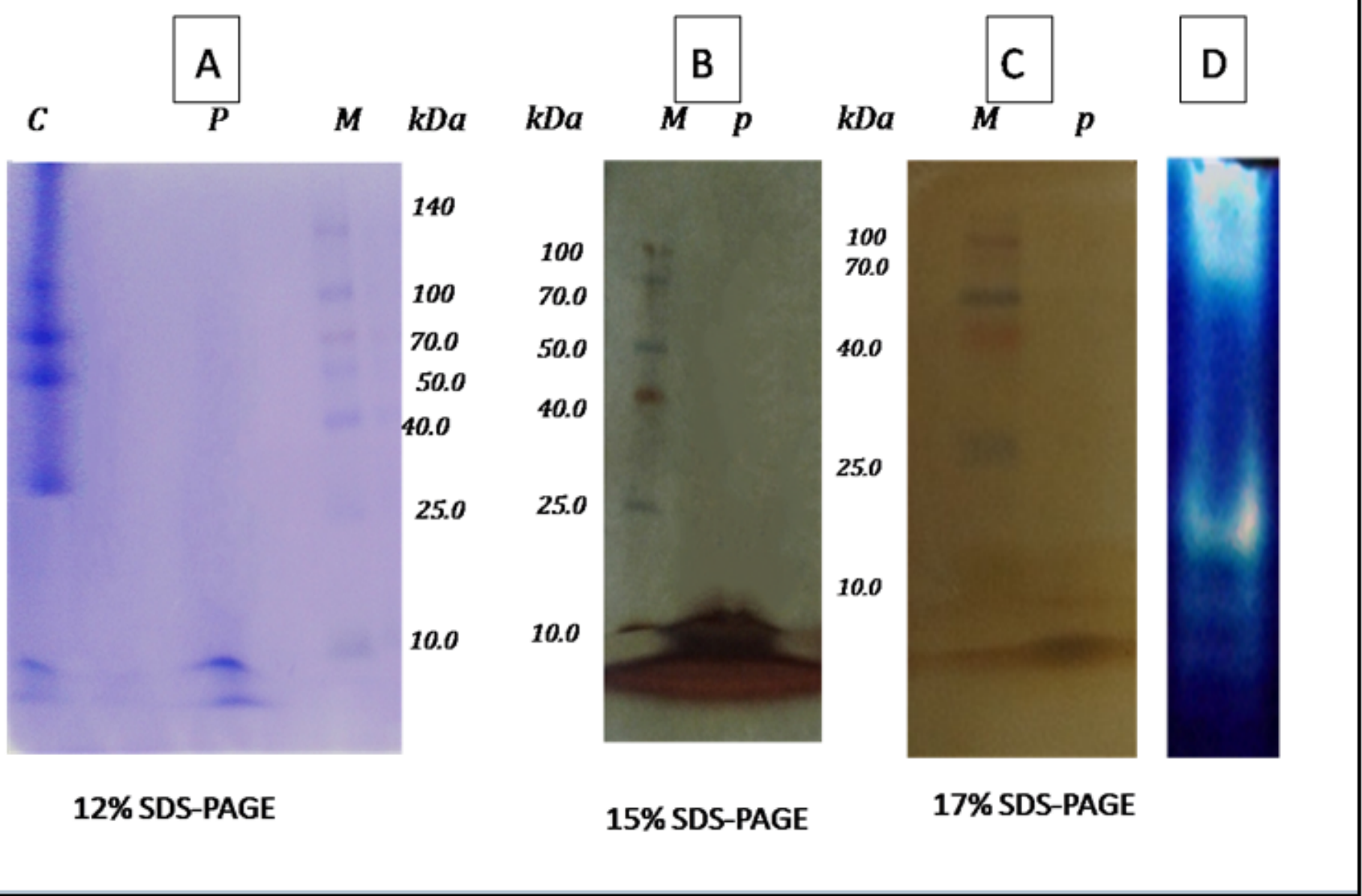

Figure 4

SDS-PAG of the partially purified protease with keratinolytic activity from laceyella sacchari YNDH. Where, (A) SDS-PAG (12\%), cell free supernatant (lane C), collected protease active fractions resulted from anion exchange column (lane P), Standard molecular mass marker (ranged 10-260 kDa) (Lane M), ( B) SDS-PAG (15\%), standard molecular mass marker (ranged 10-260 kDa) (lane M), concentrated-lyophilized cell free supernatant crude enzyme of YNDH produced in medium containing waste-feather as a carbon source (lane Cf),concentratedlyophilized cell free supernatant crude enzyme of YNDH produced in medium containing waste- nail as a carbon source . (Lane $\mathrm{Cn}$ ), collected protease active fractions resulted from anion exchange column (lane p),(C) SDSPAG (17\%), standard molecular mass marker (ranged 10-260 kDa) (lane M), concentrated-lyophilized cell free supernatant crude enzyme of YNDH produced in medium containing waste-feather as a carbon source (lane $\mathrm{C}$ ), collected protease active fractions resulted from anion exchange column (lane p), (D) Activity staining (zymogram) for a partially purified protease with keratinolytic activity from laceyella sacchari YNDH (lane d) 


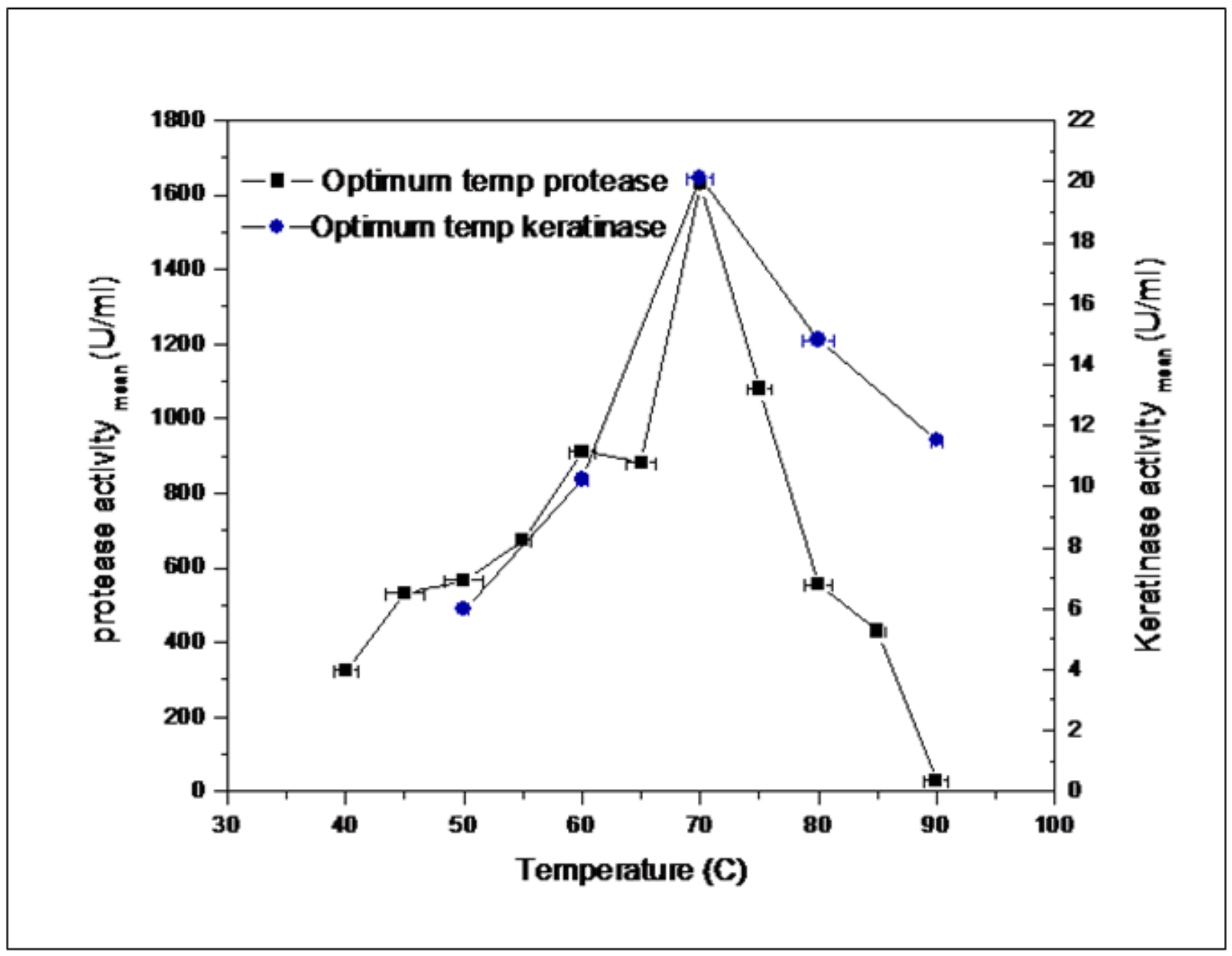

Figure 5

Optimum temperature for protease using casein as substrate and keratinase using keratin azure as substrate 


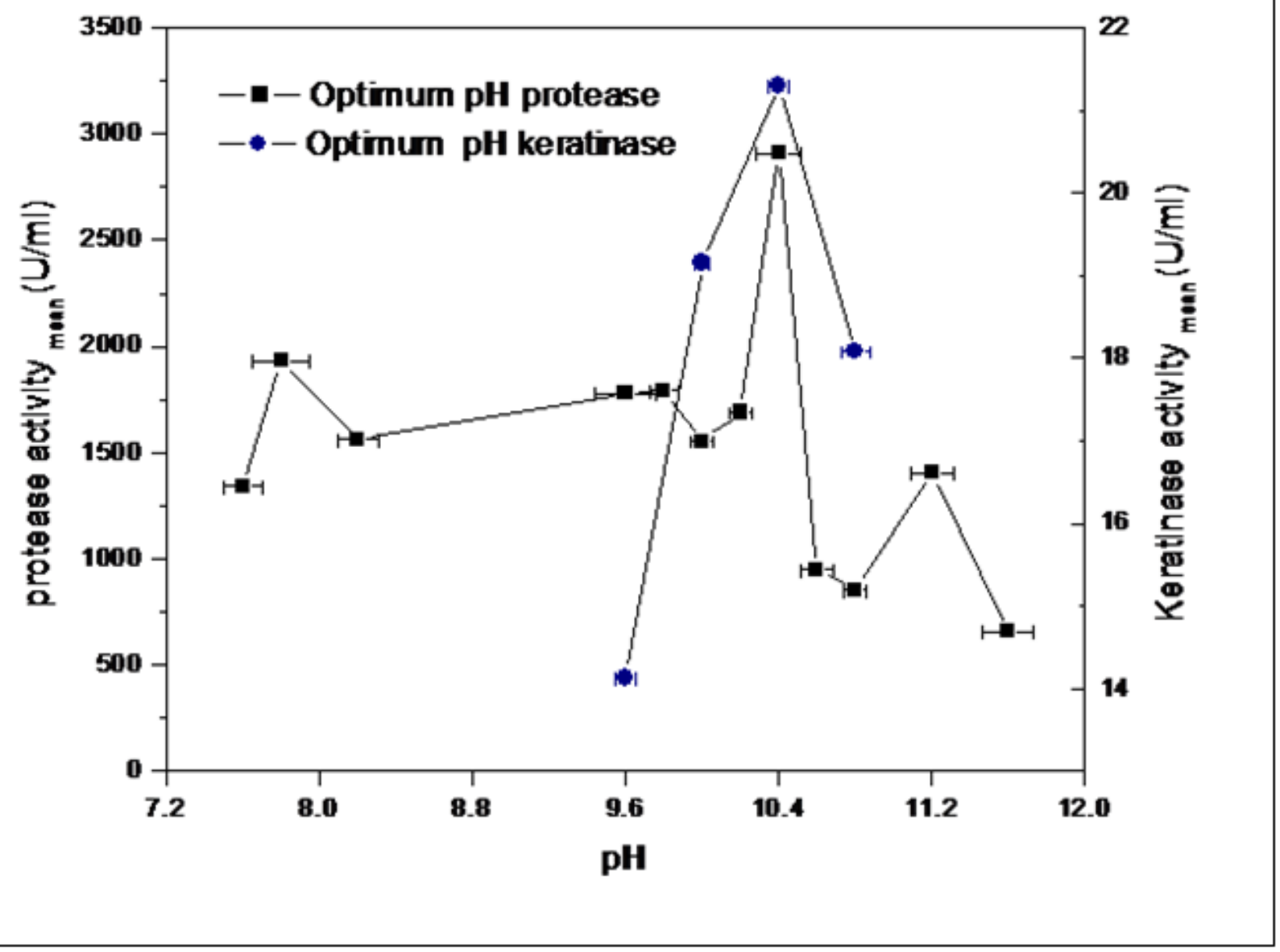

Figure 6

Optimum $\mathrm{pH}$ for protease using casein as substrate and keratinase using keratin azure as substrate 


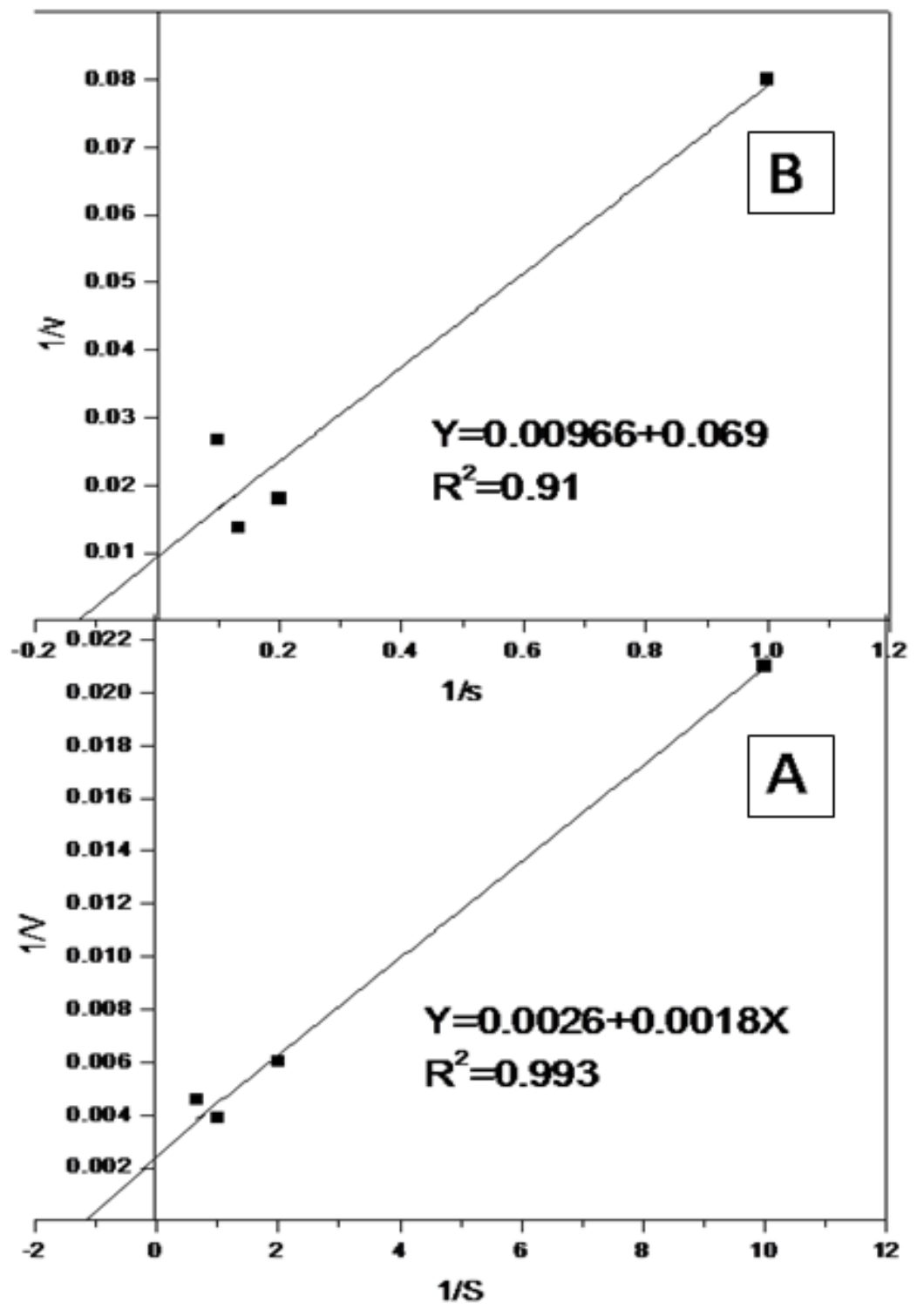

Figure 7

Lineweaver-Burk plot of partially purified enzyme (A) protease using casein as a substrate and (B) keratinase using keratin-azure as a substrate

\section{Supplementary Files}

This is a list of supplementary files associated with this preprint. Click to download.

- supplimetary.docx 